\title{
Acute encephalopathy after head trauma in a patient with a RHOBTB2 mutation
}

\author{
Annemarie C.S. Knijnenburg, MD, * Joost Nicolai, MD, PhD, * Levinus A. Bok, MD, PhD, Akin Bay, BSc, \\ Alexander P.A. Stegmann, PhD, Margje Sinnema, MD, PhD, and Maaike Vreeburg, MD, PhD
}

Neurol Genet 2020;6:e418. doi:10.1212/NXG.0000000000000418

\section{Abstract}

\section{Objective}

De novo missense mutations in the RHOBTB2 gene have been described as causative for developmental and epileptic encephalopathy.

\section{Methods}

The clinical phenotype of this disorder includes early-onset epilepsy, severe intellectual disability, postnatal microcephaly, and movement disorder. Three RHOBTB2 patients have been described with acute encephalopathy and febrile epileptic status. All showed severe EEG abnormalities during this episode and abnormal MRI with hemisphere swelling or reduced diffusion in various brain regions.

\section{Results}

We describe the episode of acute encephalopathy after head trauma in a 5-year-old RHOBTB2 patient. At admission, Glasgow coma scale score was E4M4V1. EEG was severely abnormal showing a noncontinuous pattern with slow activity without epileptic activity indicating severe encephalopathy. A second EEG on day 8 was still severely slowed and showed focal delta activity frontotemporal in both hemispheres. Gradually, he recovered, and on day 11, he had regained his normal reactivity, behavior, and mood. Two months after discharge, EEG showed further decrease in slow activity and increase in normal electroencephalographic activity. After discharge, parents noted that he showed more hyperkinetic movements compared to before this period of encephalopathy. Follow-up MRI showed an increment of hippocampal atrophy. In addition, we summarize the clinical characteristics of a second RHOBTB2 patient with increase of focal periventricular atrophy and development of hemiparesis after epileptic status.

\section{Conclusions}

Acute encephalopathy in RHOBTB2 patients can also be triggered by head trauma.
Correspondence

Drs. Knijnenburg

Annemarie.knijnenburg@mumc.nl 
Early 2018, de novo missense mutations in the RHOBTB2 gene were described as causative for a developmental and epileptic encephalopathy. ${ }^{1}$ All these mutations are located in the BTB-encoding region of the RHOBTB2 gene. The clinical phenotype of this disorder includes early-onset epilepsy, severe intellectual disability, postnatal microcephaly, and a movement disorder (dystonic, paroxysmal, or chorea-like). Recently, 3 RHOBTB2 patients with acute encephalopathy and febrile epileptic status were described. ${ }^{2}$ All showed severe EEG abnormalities during this episode and abnormal MRI with hemisphere swelling or reduced diffusion in various brain regions.

We describe the episode of acute encephalopathy of 1 child in detail and summarize the characteristics of acute encephalopathy in another patient because of a similar episode. The index case adds new information not described till now; besides fever, acute encephalopathy in RHOBTB2 patients can also be triggered by other mechanisms as head trauma.

\section{Case 1}

The index patient was born at term in 2013 as the first child from healthy nonrelated parents. He had a good start at birth. Already at the age of 4 days, seizures were noticed. He showed opisthotonus, head rotation, and did not react. On the first examination at the age of 3.5 months, poor visual fixation and mild axial hypotonia were noted. He was treated with phenobarbital and later valproic acid and levetiracetam. From the age of 1 year 2 months, new attacks were noted characterized by agitation and dystonic posturing. EEG registration proved that those attacks were nonepileptic. Despite genetic and metabolic analyses, no etiologic diagnosis could be made. Because periodic kinesigenic dyskinesia is known to react to low-dose carbamazepine, carbamazepine monotherapy was started. At the age of 2.5 years, 2 doses of carbamazepine were missed because of gastroenteritis. This resulted in frequent epileptic seizures, necessitating midazolam IV continuously. Follow-up EEG at the age of 2 years 7 months is shown in figure 1A.

Gradually, severe global psychomotor delay was noted. At the age of 2 years 8 months, trio whole exome sequencing showed a de novo mutation in de RHOBTB2 gene, c.1448 G>A (p.Arg483His), then of unknown significance. Later, the details of this boy were published (individual 2), emphasizing the need for international collaboration in the case of de novo mutations of unknown significance. The mutation was proved to be pathogenic by the in vitro analysis showing impaired degradation of the mutant RHOBTB2 by the proteasome and neurologic defects in mutant Drosophila. ${ }^{1}$

For almost 4 years, he was quite stable showing hyperkinetic dyskinesia and vivid startle reactions that were proven by simultaneous EEG recording to be epileptic. He had no long-lasting episodes of painful dystonic posturing and no other kind of seizures.

\section{Figure 1 Follow-up EEG}
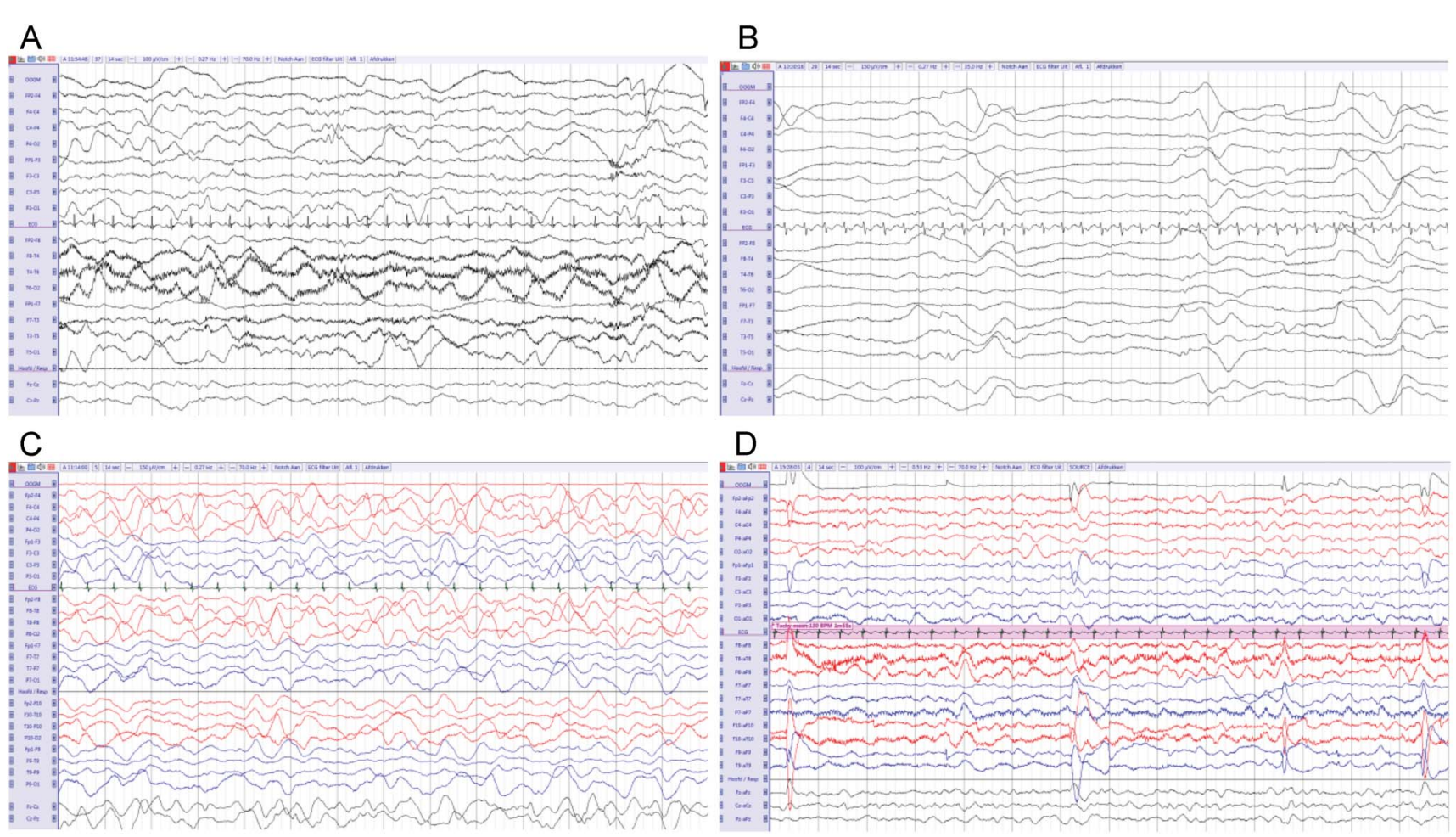

(A) Three years before admission, (B) 1 day after admission, (C) 8 days after admission, and (D) 2 months after discharge. 
In September 2018, he had a mild trauma when his head hit his bicycle. According to his parents, he was severely frightened but did not lose consciousness. A little later, he did not respond to his parents, was staring, and vomited several times. A CT scan of the brain in a local hospital did not show any traumatic injury. Because anisocoria was noted, a nonconvulsive epileptic status was suspected and treated with a single dose of midazolam IV. Several hours after the onset of symptoms, he developed fever up to $102.7^{\circ} \mathrm{F}$, and the next day, he was transported to the department of child neurology because of unexplained persistent encephalopathy.

On admission, he showed a E4M4V1 Glasgow coma scale score. His pupils showed a normal light reaction. He showed an alternating straight-forward or right-sided lateral deviation of both eyes. EEG registration was made to exclude a nonconvulsive epileptic status. EEG was severely abnormal showing a noncontinuous pattern with slow activity without epileptic activity indicating a severe encephalopathy (figure 1B).

Because of the fever and unexplained encephalopathy, viral encephalitis and bacterial meningitis were considered, and treatment with acyclovir, ceftriaxone, and dexamethasone was started. A lumbar puncture showed a mild pleocytosis $(14 \times$ $10^{6} / \mathrm{L}$ leucocytes [normal <5 × $10^{6} / \mathrm{L}$ ], 86\% granulocytes). Cultures of CSF, blood, and urine were negative. PCR viral analyses for HSV type I and type II were negative. PCR analysis of stools showed enterovirus. However, CSF analysis for enterovirus was negative.

He suffered from many seizures with unilateral clonic jerks, eye deviation, and desaturation. These were treated with midazolam nasally, increase of dose of carbamazepine, and initiation of levetiracetam. On the fourth day after the accident, he reacted a little to his parents. Because of the negative results, acyclovir, ceftriaxone, and dexamethasone were stopped. A second EEG on day 8 was still severely slowed and showed focal delta activity frontotemporal in both hemispheres (figure 1C). MRI showed subtle reduced diffusion in the hippocampal area of the left hemisphere and the right-sided hippocampal atrophy (figure 2, A and B). Gradually, he recovered, and on day 11, he regained his normal reactivity, behavior, and mood. Two months after discharge, a new EEG showed further decrease in slow activity (figure 1D).

After discharge, parents noted an increase in hyperkinetic movements. Follow-up MRI showed increment of hippocampal brain atrophy (figure 2, C and D).

Another patient with a de novo ROHBTB2 mutation, obtained by trio whole exome sequencing (also with 22q11 duplication) with an episode of encephalopathy after only mild hyperthermia $100.4^{\circ} \mathrm{F}$ and similar EEG and MRI findings was identified. We include summarized findings of both patients in the table. The parents of both patients gave consent for publication.

Figure 2 Follow-up MRI of the cerebrum
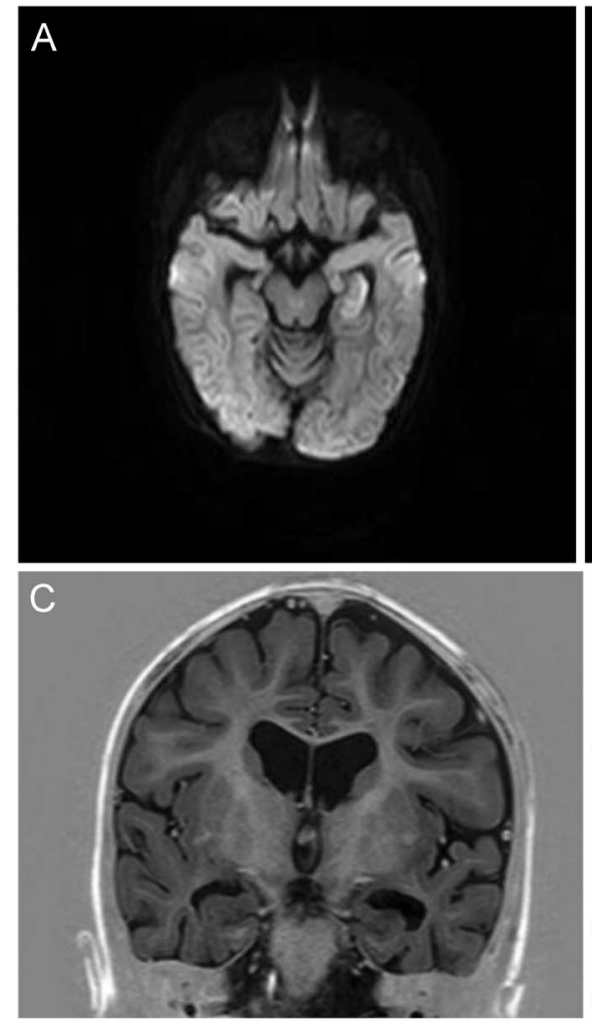
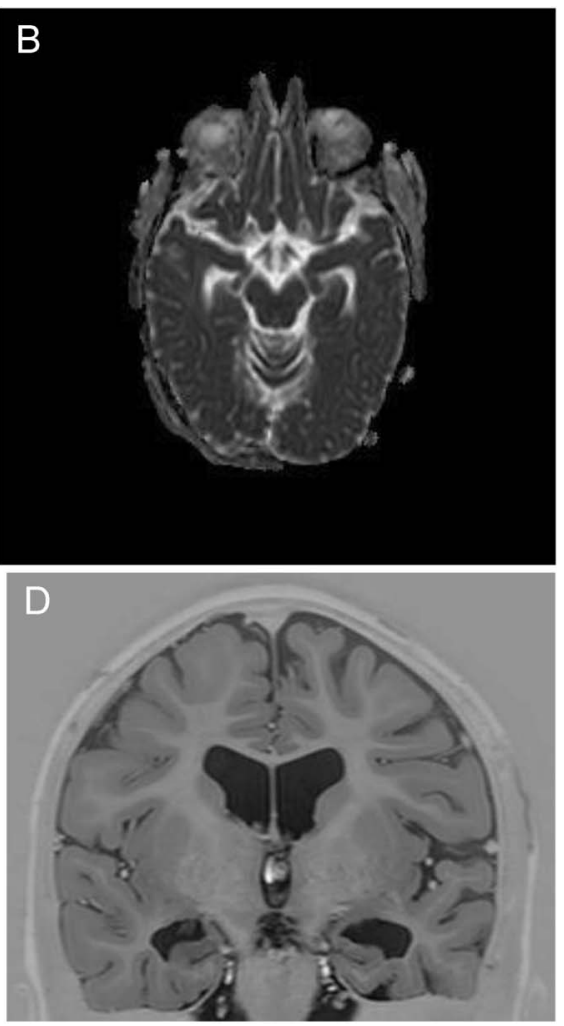

(A) DWI during admission and (B) ADC during admission, showing subtle diffusion restriction in the hippocampal area. (C) IR 3 years before admission and (D) IR 3 months after admission showing atrophy in the hippocampal area. ADC = apparent diffusion coefficient; DWI = diffusionweighted imaging; IR = inversion recovery. 


\section{Discussion}

Acute encephalopathy is a generic term for a subtype of encephalopathy mainly occurring in young children with acute brain dysfunction preceded by an infection but without evidence of a brain infection. ${ }^{3}$ Acute encephalopathy is more frequent in Japan compared with other countries in the world. This disorder can be triggered by different infections, including influenza, herpes virus type 6 , gastrointestinal infections, and RS virus. Besides, the use of NSAIDs has been proven to be a risk factor. ${ }^{3}$

Some genetic risk factors for the occurrence of postviral acute encephalopathy are known. RANBP2 mutations are found in most children with familial or recurrent acute (necrotizing) encephalopathy. ${ }^{4}$ Acute encephalopathy has also been described in children with $\mathrm{SCN}_{1} \mathrm{~A}^{5}$ and $\mathrm{SCN} 2 \mathrm{~A}$ mutations ${ }^{6}$ and in children with certain carnitine palmitoyl transferase II polymorphism ${ }^{7}$ and ADORA2A polymorphisms. ${ }^{8}$ Acute encephalopathy is not described in children with $22 \mathrm{q} 11$ duplications.

Children with de novo RHOBTB2 mutations are rarely found. Three children with a RHOBTB2 mutation were identified in a cohort of 1,230 children with infantile or early-childhood epilepsy. ${ }^{2}$ It has been found that the altered protein RHOBTB2 is relatively resistant to degradation, leading to overexpression of the altered protein. In Drosophila, overexpression of the ortholog RhoBTB is associated with seizure susceptibility and severe locomotor defects. ${ }^{1}$

The children with RHOBTB2 mutations described with acute encephalopathy have some symptoms and signs in common. First of all, it is triggered by fever or, in this case, by a mild trauma with severe frightening, with fever developing several hours after the onset of encephalopathy. The episodes are long lasting. EEG recordings are severely slowed and gradually recover. Brain MRI reveals swelling or reduced diffusion of various brain regions and can show focal atrophy over time. In addition, long-term symptoms can worsen after the recovery of an episode of acute encephalopathy.

It seems that children with a RHOBTB2 mutation do not show stable intellectual impairment, and several show regression- or stagnation-associated with the occurrence of seizures or acute encephalopathy. ${ }^{1,2,9}$ When the seizures occur at young age, this regression or stagnation is possibly not recognized.

Both our patients had an increase in clinical symptoms after acute encephalopathy and focal brain atrophy, as described in other patients with RHOBTB2 mutations. It has been described after febrile epileptic status but can also occur after head trauma or with mild fever.

Study funding

No targeted funding reported. 


\section{Disclosure}

Disclosures available: Neurology.org/NG.

\section{Publication history}

Received by Neurology: Genetics August 1, 2019. Accepted in final form February 26, 2020.

Appendix Authors

\begin{tabular}{lll}
\hline Name & Location & Contribution \\
\hline $\begin{array}{l}\text { Annemarie } \\
\text { C.S. } \\
\text { Knijnenburg, } \\
\text { MD }\end{array}$ & $\begin{array}{l}\text { Maastricht University Medical } \\
\text { Center, Maastricht, the } \\
\text { Netherlands }\end{array}$ & $\begin{array}{l}\text { Writing first draft of } \\
\text { the manuscript }\end{array}$ \\
\hline $\begin{array}{l}\text { Joost Nicolai, } \\
\text { MD, PhD }\end{array}$ & $\begin{array}{l}\text { Maastricht University Medical } \\
\text { Center, Maastricht, the } \\
\text { Netherlands }\end{array}$ & $\begin{array}{l}\text { Writing first draft of } \\
\text { the manuscript }\end{array}$ \\
\hline $\begin{array}{l}\text { Levinus A. } \\
\text { Bok, MD, PhD }\end{array}$ & $\begin{array}{l}\text { Màxima Medical Center, } \\
\text { Veldhoven, the Netherlands }\end{array}$ & $\begin{array}{l}\text { Acquisition of patient } \\
\text { data, revision of the } \\
\text { manuscript }\end{array}$ \\
\hline $\begin{array}{ll}\text { Akin Bay, BSc } \\
\text { Maastricht University Medical }\end{array}$ & $\begin{array}{l}\text { Revision of the } \\
\text { manuscript }\end{array}$ \\
\hline $\begin{array}{l}\text { Alexander P.A. } \\
\text { Stegman, PhD }\end{array}$ & $\begin{array}{l}\text { Maastricht University Medical } \\
\text { Center, Maastricht, the } \\
\text { Netherlands }\end{array}$ & $\begin{array}{l}\text { Revision of the } \\
\text { manuscript }\end{array}$ \\
\hline
\end{tabular}

Appendix (continued)

\begin{tabular}{lll}
\hline Name & Location & Contribution \\
\hline $\begin{array}{l}\text { Margje } \\
\text { Sinnema, MD, } \\
\text { PhD }\end{array}$ & $\begin{array}{l}\text { Maastricht University Medical } \\
\text { Center, Maastricht, the } \\
\text { Netherlands }\end{array}$ & $\begin{array}{l}\text { Revision of the } \\
\text { manuscript }\end{array}$ \\
$\begin{array}{l}\text { Maaike } \\
\text { Vreeburg, MD, } \\
\text { PhD }\end{array}$ & $\begin{array}{l}\text { Maastricht University Medical } \\
\text { Center, Maastricht, the } \\
\text { Netherlands }\end{array}$ & $\begin{array}{l}\text { Revision of the } \\
\text { manuscript }\end{array}$ \\
\hline
\end{tabular}

\section{References}

1. Straub J, Konrad EDH, Grüner J, et al. Missense variants in RHOBTB2 cause a developmental and epileptic encephalopathy in humans, and altered levels cause neurological defects in Drosophila. Am J Hum Genet 2018;102:44-57.

2. Belal H, Nakashima $M$, Matsumoto $H$, et al. De novo variants in RHOBTB2, an atypical Rho GTPase gene, cause epileptic encephalopathy. Hum Mutat 2018;39:1070-1075.

3. Mizuguchi M, Yamanouchi H, Ichiyama T, Shiomi M. Acute encephalopathy associated with influenza and other viral infections. Acta Neurol Scand Suppl 2007;186:45-56.

4. Gika AD, Rich P, Gupta S, Neilson DE, Clarke A. Recurrent acute necrotizing encephalopathy following influenza A in a genetically predisposed family. Dev Med Child Neurol 2010;52:99-102.

5. Saitoh M, Shinohara M, Hoshino H, et al. Mutations of the SCN1A gene in acute encephalopathy. Epilepsia 2012;53:558-564.

6. Fukasawa $\mathrm{T}$, Kubota $\mathrm{T}$, Negoro $\mathrm{T}$, et al. A case of recurrent encephalopathy with SCN2A missense mutation. Brain Dev 2015;37:631-634.

7. Shinohara M, Saitoh M, Takanashi J, et al. Carnitine palmitoyl transferase II polymorphism is associated with multiple syndromes of acute encephalopathy with various infectious diseases. Brain Dev 2011;33:512-517.

8. Shinohara M, Saitoh M, Nishizawa D, et al. ADORA2A polymorphism predisposes children to encephalopathy with febrile status epilepticus. Neurology 2013;80:1571-1576.

9. Lopes F, Barbosa M, Ameur A, et al. Identification of novel genetic causes of Rett syndrome-like phenotypes. J Med Genet 2016;53:190-199. 


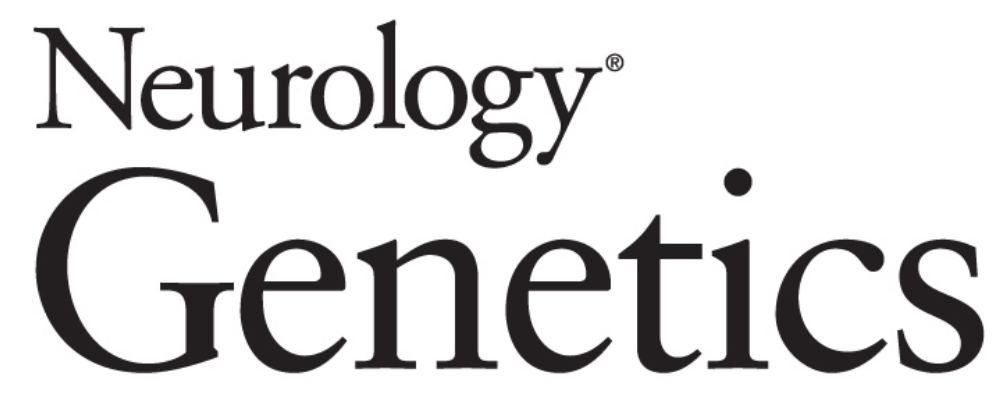

\section{Acute encephalopathy after head trauma in a patient with a RHOBTB2 mutation} Annemarie C.S. Knijnenburg, Joost Nicolai, Levinus A. Bok, et al.

Neurol Genet 2020;6;

DOI 10.1212/NXG.0000000000000418

This information is current as of April 1, 2020

\section{Updated Information \&} Services

References

Subspecialty Collections

Permissions \& Licensing

Reprints including high resolution figures, can be found at: http://ng.neurology.org/content/6/3/e418.full.html

This article cites 9 articles, 1 of which you can access for free at: http://ng.neurology.org/content/6/3/e418.full.html\#\#ref-list-1

This article, along with others on similar topics, appears in the following collection(s):

All Genetics

http://ng.neurology.org//cgi/collection/all_genetics All Trauma

http://ng.neurology.org//cgi/collection/all_trauma

Information about reproducing this article in parts (figures,tables) or in its entirety can be found online at:

http://ng.neurology.org/misc/about.xhtml\#permissions

Information about ordering reprints can be found online: http://ng.neurology.org/misc/addir.xhtml\#reprintsus

Neurol Genet is an official journal of the American Academy of Neurology. Published since April 2015, it is an open-access, online-only, continuous publication journal. Copyright Copyright $\odot 2020$ The Author(s). Published by Wolters Kluwer Health, Inc. on behalf of the American Academy of Neurology.. All rights reserved. Online ISSN: 2376-7839.

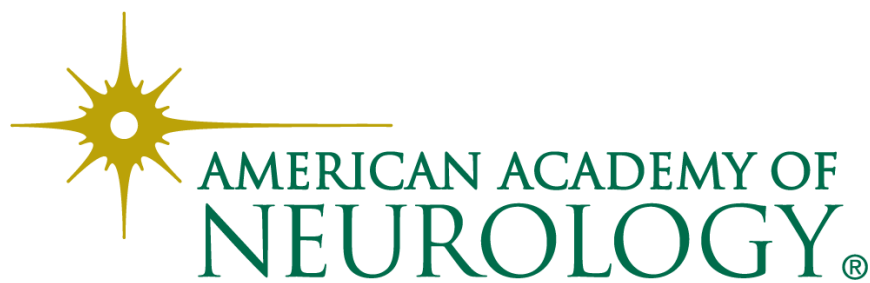

